\title{
Basis for Development of Local Public Service Primary Health Care Business Strategic Plan in Gianyar District, Bali
}

\section{Dasar Pengembangan Rencana Strategis Bisnis Puskesmas Berstatus Badan Layanan Umum Daerah di Kabupaten Gianyar, Bali}

\author{
Putu Ayu Indrayathi, Luh Putu Sinthya Ulandari
}

School of Public Health, Faculty of Medicine, Universitas Udayana, Denpasar, Indonesia

\begin{abstract}
Primary health care as Local Public Service Entity needs to make the right business strategic plan. Arranging business plan needs to pay attention to its competitors operating around its working area. This study aimed to determine internal and external environmental factors in Ubud 1 and Tegallalang 1 Primary Health Care and develop model of business strategic plan development in both primary health cares with Local Public Service Entity status. This study was descriptive explorative conducted in 2014. Data were collected through questionnaires, and documentation study. Samples were determined purposively or taken non-proportionally, consisting of Ubud 1 and Tegallalang 1 Primary Health Care heads and staff. Data were analyzed by descriptive quantitative analysis. Results of internal and external factor analysis in both primary health cares showed similar findings. Most indicators of internal variable were strength, only quantities of medical and non-medical workers were the weaknesses in program development. Meanwhile, external factor analysis showed that most indicators of external variable were opportunities and it was only people's lifestyle toward environment as the threat in program development. In conclusion, the development strategic position in Ubud 1 Tegallalang 1 was growth strategy.

Keywords: Business strategic plan, local public service entity, primary health care, SWOT analysis
\end{abstract}

\begin{abstract}
Abstrak
Puskesmas yang berbentuk Badan Layanan Umum Daerah (BLUD) perlu membuat rencana strategi bisnis yang tepat. Penyusunan rencana strategi bisnis perlu memerhatikan pesaing yang beroperasi di sekitar wilayah kerja. Penelitian ini bertujuan untuk mempelajari aspek lingkungan internal dan eksternal di Puskesmas Ubud 1 dan Tegallalang 1 serta mengembangkan model pengembangan rencana strategi bisnis di kedua puskesmas yang berstatus BLUD tersebut. Penelitian ini merupakan penelitian deskriptif eksploratif yang dilakukan pada tahun 2014. Data dikumpulkan melalui penyebaran kuesioner dan studi dokumentasi. Sampel penelitian ditentukan secara purposif dan diambil secara non proporsional, terdiri dari kepala dan staf Puskesmas Ubud 1 dan Tegallalalng 1. Data dianalisis secara deskriptif kuantitatif. Hasil analisis faktor internal dan eksternal kedua puskesmas menunjukkan hasil yang sama. Sebagian besar indikator variabel internal merupakan kekuatan, hanya kuantitas tenaga kerja bidang medis dan nonmedis sebagai kelemahan dalam pengembangan program. Sedangkan hasil analisis faktor eksternal menunjukkan sebagian besar indikator variabel eksternal merupakan peluang dan hanya perilaku masyarakat terhadap lingkungan yang merupakan ancaman dalam pengembangan program. Sebagai kesimpulan, posisi strategis pengembangan di Puskesmas Ubud 1 dan Tegallalang 1 adalah strategi pertumbuhan.
\end{abstract}

Kata kunci: Rencana strategi bisnis, badan layanan umum daerah, puskemas, analisis SWOT

How to Cite: Indrayathi PA, Ulandari LPS. Basis for development of local public service primary health care business strategic plan with local public service in Gianyar District, Bali. Kesmas: National Public Health Journal. 2016; 11 (2): 86-93. (doi:10.21109/kesmas.v11i2.846)
Correspondence: Putu Ayu Indrayathi, School of Public Health, Faculty of Medicine, Universitas Udayana, PB Sudirman street Denpasar 80232, Phone: +62361-222510,e-mail: pa_indrayathi@unud.ac.id

Received: October $1^{\text {st }} 2015$

Revised: July19th 2016

Accepted: July $28^{\text {th }} 2016$ 


\section{Introduction}

Primary health care is responsible of organizing the first level of (primary) health care within the National Health System through individual health as well as public health measures. To meet this responsibility, the primary health cares carry out several attempts, such as basic health care services and health development programs to provide comprehensive health care services to all communities in its working area. ${ }^{1}$

In the autonomy era, Gianyar District Government has a moral responsibility to develop more affordable basic health services for the people, in terms of cost and accessibility to health centers. In increasing affordability to basic health services for public, some non-inpatient care health centers were upgraded to inpatient care health centers. Furthermore, to improve services for the public, the local government establishes it in every health center that aims to provide financial flexibility, human resource management, procurement of goods and services that will implicate towards flexibility in implementing innovative programs according to community needs.

Complaints toward the low quality of services at primary health care is one of reasons for establishing primary health cares with Local Public Service Entity status in Gianyar District. ${ }^{2}$ Implementation of Local Public Service Entity in Gianyar District is the real manifestation of the government's attention in improving service quality of primary health care to public. ${ }^{3}$ Of 13 primary health cares in Gianyar District, four are primary health cares with inpatient care that provide 24-hour services. The previous studies found that the patients' perception of 'direct evidence' quality dimensions, such as alertness, confidence and attention were perceived as 'bad' and only reliability dimension that is perceived as 'good'. 4

In supporting the implementation of primary health care with Local Public Service Entity status, a proper business strategic plan is needed for optimal implementation and a review towards comprehensive health service strategy is also needed to strengthen and maintain achievements through any prioritized programs. ${ }^{5}$ Planning the business strategy also needs to pay attention to the rivals, the private health care providers operating around the same working area.

The previous studies found that Ubud 1 Primary Health Care had a very high competition density. Most healthcare facility competitors are concentrated in Ubud area, which is one of famous tourist areas in Bali, in contrast with Tegallantang 1 Primary Health Care where the number of competitor are very little. ${ }^{6}$ The competitors of Tegallalang 1 Primary Health Care are only one doctor and one midwife in private practice located approximately 1.5 kilometer from the primary health care. In Ubud 1 Primary Health Care, there are approximately 11 health facility competitors consisting of clinics, doctors and midwives where the closest distance is approximately 500 meter. $^{6}$

This study was conducted to determine internal and external environments in both Tegallalang 1 and Ubud 1 Primary Health Care that had different number of competitors, and to determine strategic business development model (grand strategy) for each primary health care.

\section{Method}

In describing the internal and external environmental aspects of the organization, this study tried to identify strengths, weaknesses, opportunities and threats (SWOT) to be considered in determining the appropriate and ideal strategy for the organization. The study was conducted from July to December 2014 in Gianyar District because this district had implemented two primary health care revitalization policies; local public service entity and 24-hour health center.

Data were collected using survey, questionnaire and documentation study. Population of this study was all Public Service Entity primary health cares' inpatients in Gianyar District. Study samples/informants were determined purposively and non-proportional. They were heads and staff of primary health cares, such as the head of administration and the head of primary health care program in Ubud 1 and Tegallalalng 1 Primary Health Cares. Quantitative data were analyzed descriptively.

Descriptive analysis was used to explain the respondents' scores of the internal factor indicators (strengths and weaknesses) and external factor (opportunities and threats) which had previously been analyzed quantitatively by calculating the average value. Furthermore, to formulate appropriate alternative strategy based on internal strengths and weaknesses and external opportunities and threats, SWOT matrix was used. In determining the strategic position as a grand strategy for the development of Tegallalang 1 and Ubud 1 Primary Health Care, an internal-external analysis matrix analysis was used.

\section{Results}

Identification of Internal Factors' Strengths and Weaknesses

Table 1 showed that the average internal environmental assessment rating in Ubud 1 Primary Health Care was good. Indicator of quantity of medical worker included in the criteria was bad with value rated 1.8 , and indicator quantity of non-medical workforce is very bad rated 1.6. This may be a weakness in the Ubud 1 health center care in Gianyar.

Table 2 showed that the average internal environment assessment toward Tegallalang 1 Primary Health Care was categorized as 'good'. However, there was 'bad' result indicating the human resource variable, consisting of quantity of medical field worker rated 2.3 and quantity of non-medical worker rated 2.2. 
Table 1. Internal Factor Analysis Summary (IFAS) of Ubud 1 Primary Health Care

\begin{tabular}{llllll}
\hline Variabel & Indicator & Value & Rating & Rating Score & Criteria \\
\hline Human resource & Quantity of medical worker & 0.053 & 1.8 & 0.0954 & Bad \\
& Quantity of non-medical worker & 0.045 & 1.6 & 0.064 & Very bad \\
& Quality of medical worker & 0.058 & 3 & 0.174 & Good \\
& Quality of non-medical worker & 0.045 & 2.7 & 0.1215 & Good \\
& Qualification of medical worker & 0.055 & 3 & 0.165 & Good \\
& Quality of non-medical worker & 0.038 & 2.7 & 0.1026 & Good \\
\multirow{5}{*}{ Operational } & Health care organization structure & 0.052 & 2.7 & 0.1404 & Good \\
& Proper infrastructure & 0.051 & 2.6 & 0.1326 & Good \\
\multirow{5}{*}{ Financial } & Proper medical equipments & 0.051 & 2.8 & 0.1428 & Good \\
& Proper medical tools & 0.048 & 2.9 & 0.1392 & Good \\
& Proper medical tools & 0.043 & 3.1 & 0.1333 & Good \\
Marketing & Financial audit system & 0.052 & 3 & 0.156 & Good \\
& Funding system & 0.052 & 3 & 0.156 & Good \\
& Drug availability & 0.048 & 2.5 & 0.12 & Good \\
& Drug quality & 0.048 & 2.9 & 0.1392 & Good \\
& Service quality & 0.052 & 3 & 0.156 & Good \\
& Tariff pattern & 0.048 & 3.1 & 0.1488 & Good \\
& Health care location & 0.059 & 3.2 & 0.1888 & Good \\
& Public relation & 0.058 & 3.1 & 0.1798 & Good \\
\hline \multirow{2}{*}{ Total } & & $\mathbf{1}$ & $\mathbf{7 1 . 4}$ & $\mathbf{2 . 6 5 5 4}$ & \\
\hline
\end{tabular}

Table 2. Internal Factor Analysis Summary (IFAS) of Tegallalang 1 Primary Health Care

\begin{tabular}{|c|c|c|c|c|c|}
\hline Variable & Indicator & Value & Rating & Rating Score & Criteria \\
\hline \multirow[t]{7}{*}{ Human resource } & Quantity of medical worker & 0.053 & 2.3 & 0.1219 & Bad \\
\hline & Quantity of non-medical worker & 0.04 & 2.2 & 0.088 & Bad \\
\hline & Quality of medical worker & 0.058 & 3.2 & 0.1856 & Good \\
\hline & Quantity of non-medical worker & 0.045 & 2.6 & 0.117 & Good \\
\hline & Qualification of medical worker & 0.055 & 3.1 & 0.1705 & Good \\
\hline & Qualification of non- medical worker & 0.038 & 2.4 & 0.0912 & Good \\
\hline & Health care organization structure & 0.052 & 3 & 0.156 & Good \\
\hline \multirow[t]{3}{*}{ Operational } & Proper infrastructure & 0.051 & 3 & 0.153 & Good \\
\hline & Proper medical equipment & 0.051 & 2.7 & 0.1377 & Good \\
\hline & Proper medical tools & 0.048 & 3 & 0.144 & Good \\
\hline \multirow[t]{3}{*}{ Finance } & Proper medical tools & 0.043 & 3.1 & 0.1376 & Good \\
\hline & Financial audit system & 0.052 & 3 & 0.156 & Good \\
\hline & Funding system & 0.052 & 3 & 0.1716 & Good \\
\hline \multirow[t]{6}{*}{ Marketing } & Drug availability & 0.048 & 2.5 & 0.1248 & Good \\
\hline & Drug quality & 0.048 & 2.9 & 0.1392 & Good \\
\hline & Service quality & 0.052 & 3 & 0.156 & Good \\
\hline & Tariff pattern & 0.048 & 3.1 & 0.144 & Good \\
\hline & Health care location & 0.059 & 3.2 & 0.1947 & Good \\
\hline & Public relation & 0.058 & 3.1 & 0.1856 & Good \\
\hline Total & & 1 & 44.2 & 2.9459 & \\
\hline
\end{tabular}

Table 1 and Table 2 showed the value of large or small weighting, since it indicated the relative significance of a factor to the success of an organization. The greatest weight (value) in marketing variable were the location of health care (0059), relation with the public (0058), meanwhile the greatest weight (value) in the human resources variable was quality of medical worker (0058). These figures showed that these indicators were important and strategic in the service development program.

\section{Identification of External Factors: Opportunities and Threats}

Based on the analysis of external factors in Ubud 1 Primary Health Care (Table 3), most external factor in- dicators reflected a good external environment. Transportation and public education indicators in Gianyar had the highest rating value that was 3.2 with good criteria. While the indicator of people's behavior towards the environment had the lowest rating value, that was 2.3 with bad criteria.

Table 4 showed the analysis result of external conditions of Tegallalang 1 Primary Health Care in which transportation had the highest rating value that was 3.1 with good criteria and people's behavior towards the environment as the lowest rating indicator that was 2.3 with bad criteria.

Table 3 and Table 4 that mentioned the weighting of 
Table 3. External Factor Analysis Summary (EFAS) of Ubud 1 Primary Health Care

\begin{tabular}{|c|c|c|c|c|c|}
\hline Variable & Indicator & Value & Rating & Rating Score & Criteria \\
\hline \multirow[t]{5}{*}{ Economy } & Drug price level & 0.07 & 2.7 & 0.189 & Good \\
\hline & Public purchasing power & 0.066 & 2.9 & 0.1914 & Good \\
\hline & Transportation facility & 0.066 & 3.2 & 0.2112 & Good \\
\hline & Medical worker availability & 0.066 & 2.6 & 0.1716 & Good \\
\hline & Local government's health budget & 0.07 & 3 & 0.21 & Good \\
\hline \multirow[t]{3}{*}{ Legal } & Public health law implementation & 0.07 & 2.9 & 0.203 & Good \\
\hline & Local public health agency health care legal protection & 0.066 & 2.8 & 0.1848 & Good \\
\hline & Local public health entity health care implementation & 0.07 & 3 & 0.21 & Good \\
\hline \multirow[t]{3}{*}{ Socio culture } & Education level of Gianyar people & 0.07 & 3.2 & 0.224 & Good \\
\hline & Population of Gianyar & 0.063 & 3 & 0.189 & Good \\
\hline & People's behavior towards environment & 0.055 & 2.3 & 0.1265 & Bad \\
\hline \multirow{4}{*}{$\begin{array}{l}\text { Development of health } \\
\text { science technology }\end{array}$} & & 0.066 & 3 & 0.198 & Good \\
\hline & Health equipment technology development & 0.07 & 3 & 0.21 & Good \\
\hline & Information technology development & 0.066 & 3 & 0.198 & Good \\
\hline & Communication technology development & 0.063 & 3 & 0.189 & Good \\
\hline
\end{tabular}

Table 4. External Factor Analysis Summary (EFAS) of Tegallalang 1 Primary Health Care

\begin{tabular}{|c|c|c|c|c|c|}
\hline Variable & Indicator & Value & Rating & Rating Score & Criteria \\
\hline \multirow[t]{5}{*}{ Economy } & Drug price level & 0.07 & 3 & 0.21 & Good \\
\hline & Public purchasing power & 0.066 & 3 & 0.198 & Good \\
\hline & Transportation facility & 0.066 & 3.1 & 0.2046 & Good \\
\hline & Medical worker availability & 0.066 & 2.8 & 0.1848 & Good \\
\hline & Local goverment's health budget & 0.07 & 3 & 0.21 & Good \\
\hline \multirow[t]{3}{*}{ Legal } & Public health law system implementation & 0.07 & 3 & 0.21 & Good \\
\hline & Local public health agency health center legal protection & 0.066 & 3 & 0.198 & Good \\
\hline & Local public health entity health care implementation & 0.07 & 3 & 0.21 & Good \\
\hline \multirow[t]{4}{*}{ Socio culture } & Education level of Gianyar people & 0.07 & 3 & 0.21 & Good \\
\hline & Population of Gianyar & 0.063 & 3 & 0.189 & Good \\
\hline & People's behavior towards environment & 0.055 & 2.3 & 0.1265 & Bad \\
\hline & Health science development & 0.066 & 3 & 0.198 & Good \\
\hline \multirow[t]{3}{*}{ Technology } & Health equipment technology development & 0.07 & 3 & 0.21 & Good \\
\hline & Information technology development & 0.066 & 3 & 0.198 & Good \\
\hline & Communication technology developmnet & 0.063 & 3 & 0.189 & Good \\
\hline Total & & 1 & 44.2 & 2.9459 & \\
\hline
\end{tabular}

indicators showed that cost of medicines, local government's health budget, the implementation of local public entity health care's legal protection, the implementation of local public entity health care's law, Gianyar people's education level and medical technology development had higher weight values $(0.07)$ than other external variable indicators. These indicated that the indicators had higher role than other indicators for both health cares in developing priority programs.

\section{Internal-External Matrix}

As shown in Table 1 and Table 3, the total weighted value of Ubud 1 Primary Health Care for the Internal Factor Analysis Summary (IFAS) score was 2.6554 and External Factor Analysis Summary (EFAS) score was 2.9005. These scores were not much different from the weighted value of Tegallantang 1 Primary Health Care as seen in Table 2 and Table 4. The value of IFAS score was 2.9459 and EFAS score was 2.9459. The position of
Tegallalang 1 and Ubud 1 Primary Health Care were presented in the following Figure 1.

In Figure 1, the position of Tegallalang 1 and Ubud 1 Primary Health Care were in the quadrant V (Growth) with a horizontal integration concentration. Hence, the grand strategy that could be implemented by both Tegallalang 1 and Ubud 1 Primary Health Care were increasing service variance and health care service quality.

\section{SWOT Matrix}

The SWOT matrix (Table 5) provided the right alternative strategy for Tegallalang 1 and Ubud 1 Primary Health Care, considering the similar position indicator in both primary health cares. This matrix described the overview of the overall strategy of Tegallalang 1 and Ubud 1 Primary Health Care based on internal strengths and weaknesses as well as external opportunities and threats.

Following the SWOT analysis suggestion, the strate- 


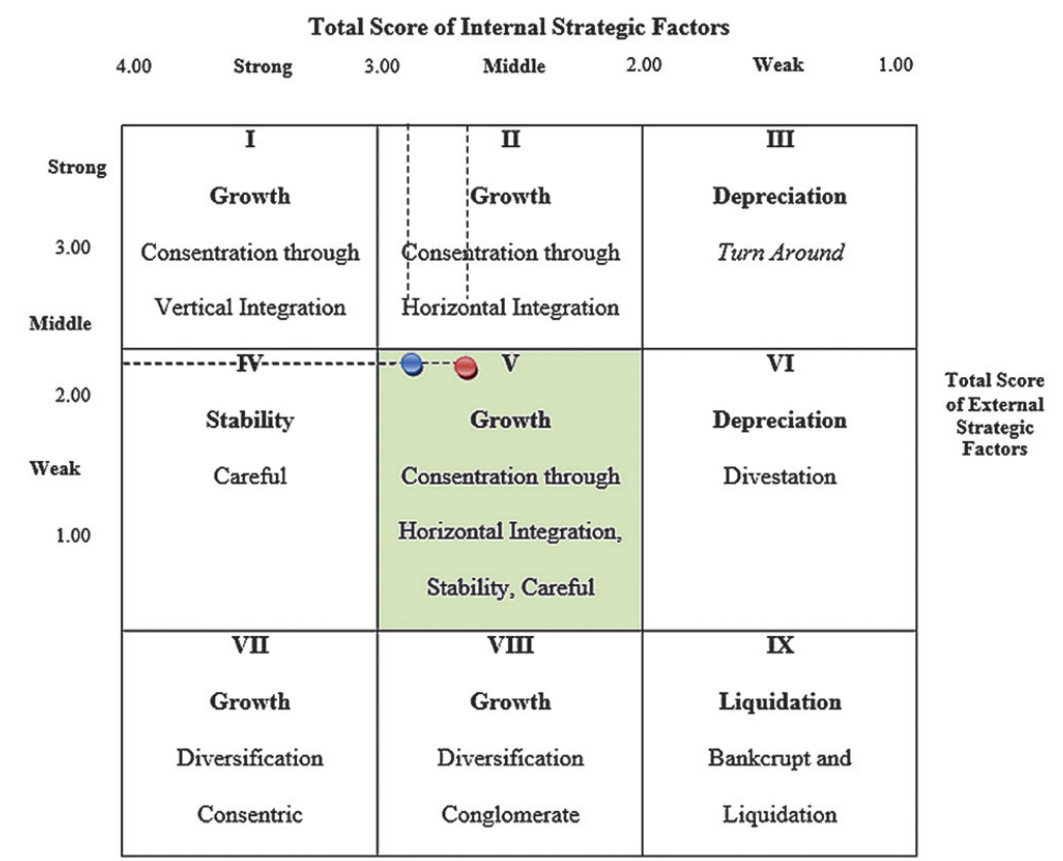

Figure 1. Internal-External Matrix of Ubud 1 dan Tegallalang 1 Primary Health Care Total Score of Internal Strategic Factors (data source modified from David, et $a l^{7}$ )

Table 5. SWOT Matrix of Ubud 1 and Tegallalang 1 Primary Health Care

\begin{tabular}{|c|c|c|c|}
\hline Strength (S) & Weakness (W) & Opportunity (O) & Threat (T) \\
\hline $\begin{array}{l}\text { Medical worker quanlity } \\
\text { Non-medical worker quantity } \\
\text { Medical worker qualification } \\
\text { Health care organization structure } \\
\text { Proper infrastructure } \\
\text { Proper medical equipment } \\
\text { Proper medical supply } \\
\text { Health care budget and expenditure } \\
\text { Financial audit system } \\
\text { Funding system } \\
\text { Drug availability } \\
\text { Drug quality } \\
\text { Service quality } \\
\text { Tariff pattern } \\
\text { Health care location } \\
\text { Public relation }\end{array}$ & $\begin{array}{l}\text { Medical worker quantity } \\
\text { Non-medical worker quantity }\end{array}$ & $\begin{array}{l}\text { Drug price level } \\
\text { Non-medical worker qualification } \\
\text { Public purchasing power } \\
\text { Transportation facility } \\
\text { Medical worker availability } \\
\text { Local government's health budget } \\
\text { Public health legal system implementation } \\
\text { Local public service entity legal protection } \\
\text { Local public service entity legal implementation } \\
\text { Gianyar people's education level } \\
\text { Health science development } \\
\text { Health equipment technology development } \\
\text { Communication equipment technology develop- } \\
\text { ment }\end{array}$ & People's behavior towards environment \\
\hline Strategy SO & Strategy WO & Strategy ST & Strategy WT \\
\hline $\begin{array}{l}\text { To carry out prioritized health } \\
\text { program according to the local } \\
\text { people's needs by mainstreaming } \\
\text { consumer's satisfaction }(\mathrm{S} 14, \mathrm{~S} 17, \text { )2) }\end{array}$ & $\begin{array}{l}\text { To add the number of medical } \\
\text { worker according to workload } \\
\text { (W1, O4, 05, 08) } \\
\text { To add the number of non-medical } \\
\text { worker based on outsourcing pat- } \\
\text { tern according to health care } \\
\text { budget, revenue and expenditure } \\
\text { (W2, O5,O8) }\end{array}$ & $\begin{array}{l}\text { To encourage health promotion in every } \\
\text { sub-health center and persuade people to pay } \\
\text { attention to the environmental health condition } \\
(\mathrm{S} 17, \mathrm{~T} 1)\end{array}$ & $\begin{array}{l}\text { To empower karang taruna (local youth } \\
\text { organization) in the health care working } \\
\text { area to be the environmental health } \\
\text { agent in that region (W1, T1) }\end{array}$ \\
\hline
\end{tabular}

gies to be implemented by both health cares to increase the service variance and quality were managing health prioritized programs according to the needs of local people with emphasis on costumer's satisfaction, adding more medical worker based on the workload, and nonmedical worker through outsourcing based on health care's budget, revenue and expenditure, intensifying health promotion in every sub-health care, persuading people to pay more attention to environmental health, and empowering the local youth organization in the health care region to be agent of environmental health promotion environment. 


\section{Discussion}

Analysis results of the internal environmental found that both health cares obtained good rating. Quantity of the medical and non-medical worker were rated bad in both health cares. This was certainly health care's weakness in the administration of health care programs, due to imbalances between tasks and workforce. This study was in line with Susanto's study in North Bontang II Primary Health Care 2014 that found manpower shortage seen from the imbalance of tasks and the number of health workers in the morning and an afternoon shifts, causing the employee's workload was considered heavy. ${ }^{8}$

In connection with this, it was necessary to increase the amount of medical personnel. Based on Bali Provincial Health Profile 2013, Gianyar still had a shortage of 113 physicians, 241 nurses, and 168 midwives. ${ }^{9}$ In addition, non-medical administrative work was still concurrently held by paramedics, causing not maximum human resource performance. This finding was in line with Wibowo's, 10 study in 2011 that found many administrative work in health cares were held by health personnels, such as nurses or midwives, which indicated that nonmedical personnels in East Java health cares were still not enough.

Performing administrative activities in health care with inpatient care by health personnels, such as nurses and midwives, would lead to a decrease in the concentration, be unfocused and decline health care performance in services to the public. ${ }^{10}$ In line with this was findings of Handayani et al., 11 that there were $53.9 \%$ of health care health workers got additional tasks, and $56.6 \%$ of the $53.9 \%$ stated that the additional tasks sometimes interfere with their main duties and functions in providing health care in the health care. In this case, additional non-medical worker through outsourcing patterns was necessary considering limited non-medical workers and budget available. There were still many concurrent responsibilities held by medical personnels, such as nurses and midwive. ${ }^{3}$

IFAS results indicated that health care location, relation with the public and the quality of medical worker had high weight value and became the important indicator and strategic in service development program. The quality of medical personnel had an important role as stated by Tomar and Dhiman, 12 in 2013 that the quality of medical personnel was important in stimulating the patient's recovery, especially their hospitality and special attention to patient.

Location also affects the use of health care because people prefer to use health facilities close to where they live in and accessibility. This was in line with Sutiarini's, ${ }^{3}$ study in 2011 who stated that location of health cares in the society could improve public accessibility to health care services. Tegallalang 1 Primary Health Care is situ- ated some distance from the city center and the crowd. In addition, the rival health facilities either private clinics or private midwives were not as dense as in Ubud 1 Primary Health Care. Bringing about the existence of a health care offering inpatient care is very effective. In the area with densed competitors, strategies are needed to attract consumers to come to the clinic for treatment of care by strengthening promotion and service quality. ${ }^{6}$

At the operational variables of Ubud 1 Primary Health Care, the infrastructure, medical equipment and medical supplies indicators had rating value ranged from 2.6 to 2.9. Despite included in the good value criteria, the value was less than 3 . These suggested that improved infrastructure, medical equipment and medical supplies were needed because these would affect patient's satisfaction and health care service quality. Some study findings, such as conducted by Boller et al., 13 Andaleeb et al., ${ }^{14}$ Baltussen et al., ${ }^{15}$ and Duong et al., ${ }^{16}$ successfully identified that the medical facility was part of quality dimension of inpatient care.

Study of Sharma and Narang in Wibowo, ${ }^{10}$ stated that medical facilities had significant relation with patients revisit in ambulatory care. Khristiani, ${ }^{17}$ concluded that development of the health care quality design could be carried out in the following order. The first priority was wellmaintained inpatient services infrastructure, then followed by availability of medical facilities and medical support and availability of 24-hour ambulance transport. ${ }^{17}$

In contrast to the Tegallalang 1 Primary Health Care, only medical equipment rating value was still below 3 (2.7). Despite qualified as good, it needed to be increased. The results were in line with Duana's study, 18 that found $29.11 \%$ of respondents said that the completeness of Tegallalang 1 Primary Health Care equipment was bad. Kotler, ${ }^{19}$ also stated that one of the efforts taken by the company management that primarily related directly to the customer's satisfaction was by providing the best possible facilities to attract and retain customers, such as providing convenience, needs and comfort for the service users. Facilities as seen by the consumers were part of the important tangible manifestation of the overall service offered. ${ }^{20}$

The comfort level within health care organization also needed to be considered aside from facilities and equipment. This was in accordance with the opinion of Sabarguna who also stated that health organizations needed to keep the comfort besides ensuring proper equipment. ${ }^{21}$ The study also noted that 18 respondents $(22.7 \%)$ stated that the completeness and the readiness of the equipment were as the reason not to utilize the delivery services at Tegallalang 1 Primary Health Care. ${ }^{21}$ Infrastructure and supporting facilities for inpatient care would determine the quality of service and ultimately had 
an impact on health care inpatient's satisfaction and loyalty. Based on the analysis of internal environment, the total weighted IFAS value was 2.6554 at Ubud 1 Primary Health Care and 2.9459 at Tegallalang 1 Primary Health Care health showing that almost all of internal indicators were the strength factors in the development of services of both health cares.

At Ubud 1 Primary Health Care, indicator of drug prices and purchasing power still had rating value below 3 , despite included in the good category. The drug price level needed to be reviewed by the relevant health cares in providing health services to the people, since it would affect people's purchasing power. The results of the external environment analysis showed that people's behavior was a threat indicator in the development of health care service program. People's behavior toward the environment and healthy living habits needed to be instilled in the people themselves, since people's behavior towards the environment was closely related to disease spread in that area. ${ }^{9}$ The total of EFAS value at Ubud 1 Primary Health Care was 2.9055 and 2.9459 at Tegallalang 1 Primary Health Care, showing that both health cares were in a good position to develop the health center program by leveraging existing opportunities.

The strategic position of Tegallalang 1 and Ubud 1 Primary Health Care in Gianyar District in developing health services was at the same concentration in growth strategy through horizontal integration, although they had different number of competitors. In connection with the growth strategy positions with horizontal concentration integration, then the grand strategy that could be applied by Tegallalang 1 and Ubud 1 Primary Health Care as the primary health cares with Local Public Service Entity status was to increase variance and quality of health care services.

This was in accordance with the opinion of Rangkuti, 22 that strategy was effort to design growth, either in sales, assets, profits or combination of those three, whereas that could be achieved by developing new products, lowering prices, increasing product quality or services, or improving access to a broader market. ${ }^{22}$ These findings were in line with study conducted by Dias, ${ }^{23}$ that suggested an increasing quality of essential health care services in public health through monitoring and evaluation of health services and the strengthening of health care service provider institutions. Perspectives on service quality improvement in health service strategy as also presented by Violeta, ${ }^{24}$ stating that improving the quality of health care services could be appreciated by patients as customers through increasing human resources, facilities, infrastructure, facilities and service processes.

\section{Conclusion}

In the internal environmental factor analysis towards both health cares, two indicators are identified as weakness. They are quantity of medical and non-medical workers. Meanwhile, in the results of the external environment analysis, there only one indicator namely people's behavior towards the environment is identified as threat. The strategic position in the development of Ubud 1 and Tegallalang 1 Primary Health Care is a growth strategy with horizontal integration concentration. Hence, the grand strategy that can be implemented is increasing variance of products and quality of service. It is very likely to be implemented by the Local Public Service Entity primary health cares the policy that can provide flexibility to the health care to develop their own flagship program according to the needs of each health care based on characteristics of the served population and working area.

\section{Recommendation}

This study suggests that to address the weaknesses that still exist, it is necessary to add the number of medical worker through any calculation of the workload, and make a planning for non-medical staff recruitment in the health care level using outsourcing patterns according to the health care's revenue and expenditure budget and priorities. Then it needs mapping and analysis of public health in each health care working area.

\section{Acknowledgment}

A sincere gratitude is submitted to the Ministry of Research, Technology and Higher Education of the Republic of Indonesia and the Institute for Research and Community Service of Universitas Udayana for funding this study as well as to Gianyar District Health Agency and all respondents involved.

\section{References}

1. Kementerian Kesehatan Republik Indonesia. Kebijakan dasar puskesmas. Jakarta: Kementerian Kesehatan Republik Indonesia; 2014.

2. Dinas Kesehatan Kabupaten Gianyar. Laporan kunjungan pasien Puskesmas Kabupaten Gianyar Tahun 2012. Gianyar: Dinas Kesehatan Kabupaten Gianyar.; 2012.

3. Sutiarini NK. Analisis SWOT untuk rencana strategik pengembangan badan layanan umum daerah (BLUD) Puskesmas di Kabupaten Gianyar [postgraduate thesis]. Denpasar: Program Pasca Sarjana Universitas Udayana; 2011.

4. Indrayathi PA, Listyowati R, Nopiyani NMS, Ulandari LPS. Mutu pelayanan puskesmas perawatan yang berstatus Badan Layanan Umum Daerah (BLUD). Kesmas: Jurnal Kesehatan Masyarakat Nasional. 2014; 9(2): $164-70$.

5. David FR. Manajemen strategis konsep. Edisi ke-12. Jakarta: Salemba Empat; 2006.

6. Indrayathi PA, Mulyawan KH, Dewi PNT. Pemetaan berdasarkan lokasi dan jumlah pesaing puskesmas perawatan di Kabupaten Gianyar yang berstatus BLUD sebagai dasar penyusunan strategi bisnis. Jurnal Archive of Community Health. 2009; 3(1): 56 - 64 . 
7. David FR. Manajemen strategis. Edisi ke-tujuh. Jakarta: PT Prenhallindo; 2004.

8. Susanto H. Pengaruh fasilitas kesehatan terhadap kinerja pegawai pada Puskesmas Bontang Utara II di Kecamatan Bontang Utara Kota Bontang. eJournal Administrasi Negara. 2014; 12(1): 367-81.

9. Dinas Kesehatan Provinsi Bali. Profil Kesehatan Provinsi Bali tahun 2013. Denpasar: Dinas Kesehatan Provinsi Bali; 2013.

10. Wibowo NM. Strategi pengembangan pelayanan rawat inap puskesmas berbasis service delivery system. Jurnal Ekonomi dan Keuangan. 2013; 17(3): $337-56$.

11. Handayani LN, Ma'ruf A, Sopacua E. Peran tenaga kesehatan sebagai pelaksana pelayanan kesehatan puskesmas. Buletin Penelitian Sistem Kesehatan. 2010; 13(1): 12-20.

12. TomarA, Dhiman A. Exploring the role of HRM in service delivery in health care organizations: A study of an Indian Hospital. Vikalpa. 2013; 38(2): 21-39.

13. Boller C, Wyss K, Mtasiwa D, Tanner M. Quality and comparison of antenatal care in public and private providers in the United Republic of Tanzania. Bulletin of the World Health Organization. 2003; 81(2): 11622.

14. Andaleeb SS. Public and private hospital in Bangladesh: service quality and predictors of hospital choice, health policy and planning. 2000; 15(1): 95-102.

15. Baltussen RM, Ye Y, Haddad S, Sauerborn RS. Perceived quality of care of primary health care services in Burkina Faso. Health Policy Planning. 2002; 17: 42-8
16. Duong DV, Binns CW, Lee AH, Hipgrave DB. Measuring client-perceived quality of maternity services in Rural Vietnam. International Journal of Quality Health Care. 2004; 6: 447-57.

17. Kristiani YR, Kuntjoro T, Utarini A. Pengembangan desain mutu pelayanan rawat inap Puskesmas Karanganyar Kebumen menggunakan quality function deployment. Jurnal Manajemen Pelayanan Kesehatan. 2006; 9(4): 209-14.

18. Duana K. Persepsi dan harapan ibu terhadap kualitas pelayanan persalinan di Puskesmas Tegalalang I Kecamatan Tegalalang Kabupaten Gianyar [undergraduate thesis]. Denpasar: Program Studi Kesehatan Masyarakat Universitas Udayana; 2005.

19. Kotler P. Manajemen pemasaran: analisis, perencanaan, implementasi, dan kontrol. Jakarta: PT. Prehallindo; 2001.

20. Lamb CW, Hair JF, Daniel CM. Marketing. United States of America: South Western College Publishing; 2002.

21. Sabarguna B. Pemasaran rumah sakit. Yogyakarta: Konsorsium RSI; 2004.

22. Rangkuti F. Analisa SWOT teknik membedah kasus bisnis. Jakarta: PT. Gramedia Pustaka Utama; 2008.

23. Dias C. The future of public health services in Europe: strategic intersection with healthcare services. International Journal of Healthcare Management. 2012; 5 (2): 69-73.

24. Violeta R, Iuliana C, Mihaela BA. Improving quality strategies in the health services marketing. Annals of the University of Oradea, Economic Science Series. 2008; 17 (4): 1159-63. 